\title{
ВИКОРИСТАННЯ ІНТЕРАКТИВНИХ МЕТОДІВ НАВЧАННЯ У МЕДИЧНИХ УНІВЕРСИТЕТАХ АВСТРІЇ
}

Г. І. Кліш

\author{
ДВНЗ “Тернопільський держсавний медичний університет імені І. Я. Горбачевського МОЗ Украйни”
}

\section{USING INTERACTIVE TEACHING METHODS IN MEDICAL UNIVERSITIES IN AUSTRIA}

\author{
H. I. Klishch \\ SHEI "Ternopil State Medical University by I. Ya. Horbachevsky of MPH of Ukraine"
}

\begin{abstract}
У статті розкрито суть інтерактивних методів навчання, які забезпечують оптимізацію навчального процесу. Охарактеризовано основні інноваційні методи, що застосовуються у вищих медичних закладах Австрії. Висвітлено актуальність упровадження інтерактивного навчання в освітній процес.
\end{abstract}

The article presents the essence of interactive teaching methods that ensure optimization of educational process. The basic innovative methods used at the Austrian medical universities are characterized. The urgency of the introduction of interactive learning in the educational process is analyzed.

Вступ. Реформування національної системи освіти України, сучасні тенденції світової інтеграції зводять проблему розвитку особистості в ранг пріоритетних завдань. Основними компонентами у “піраміді навчання" виступають педагогічні парадигми, моделі навчання, технології й методики, елементи технологій. Навчання передбачає партнерство, взаємодію викладача і студента, активність та ініціативність студента, його самостійність [1].

Розвиток української медичної освіти, кінцевою метою якого є підготовка висококваліфікованого лікаря, який би відповідав сучасному рівню розвитку медичної науки і вимогам суспільства, грунтується на впровадженні якісно нової методології організації навчального процесу за європейським зразком: в основу концепції закладено європейські тенденції та національну стратегію [6].

У цьому контексті значний інтерес становить досвід Австрії, де медична освіта має багатолітні традиції. Важливість вивчення досвіду цієї держави підтверджується тим, що вона займає провідні позиції з розробки та впровадження освітніх інновацій і при цьому вирізняється зваженим підходом до проблеми оптимального поєднання національних традицій із актуальними тенденціями розвитку світових систем медичної освіти.

Основна частина. Сучасне інформаційне суспільство ставить завдання підготовки спеціалістів, здатних

(ㄷ. Г. І. Кліщ адаптуватися у різних життєвих ситуаціях, самостійно набувати необхідних знань, грамотно працювати 3 інформацією, критично мислити, самостійно працювати над розвитком інтелекту та культурного рівня.

Передовий педагогічний досвід засвідчує, що використання інтерактивних технологій навчання дає можливості для пошуку нових форм і методів викладання, для підвищення професійної компетентності, для покращення та удосконалення навчального процесу.

Педагогічною наукою накопичено значний досвід щодо активізації навчально-пізнавальної діяльності студентів. Проблема активізації пізнавальної діяльності у процесі навчання в педагогічній теорії й практиці не нова. На всіх етапах розвитку педагогічної думки до неї зверталося багато вчених, педагогівпрактиків.

Аналіз останніх досліджень та публікацій дає змогу зазначити, що використання інтерактивних технологій у навчально-виховному процесі привертає увагу багатьох учених і педагогів. Зокрема, С. Кашлєв обгрунтував інтерактивне навчання як інноваційне педагогічне явище, О. Пометун опублікувала “Енциклопедію інтерактивного навчання" та велику кількість робіт з даної проблеми, М. Кларін розглядав інтерактивне навчання як інструмент освоєння нового досвіду, Т. Дуткевич визначає психологічні основи використання інтерактивних методів у процесі підготовки спеціалістів з вищою освітою. Теоретичний і дидактичний аспекти інтерактивних техно- 
логій навчання розроблені та висвітлені в роботах М. Башмакова, В. Беспалька, Л. Буркової, В. Лозової, Г. Селевка, О. Пєхоти та інших вітчизняних і зарубіжних вчених [7].

Інтерактивне навчання - це спеціальна форма організації пізнавальної діяльності, яка має конкретну, передбачувану мету - створити комфортні умови для навчальної взаємодії студентів, отримання студентами у співпраці колективного інтелектуального продукту - знання та відповідного досвіду пізнавальної діяльності $[2,4]$.

Перевагами інтерактивних технологій і методів навчання є взаємодія всіх учасників при роботі в малих групах, емоційна залученість й активність кожного в процесі роботи; підвищення рівня засвоєння матеріалу студентами при практичному застосуванні отриманих знань; навчання у дискусії, що формує процес мислення й професійні вміння [3]; формування світогляду та сприяють особистісному розвитку; розвивають комунікативну компетентність, необхідну для спеціалістів, що працюють у галузі людських відносин [5].

Впровадження інтерактивних методик у викладання фахових дисциплін дає змогу докорінно змінити ставлення до об'єкта навчання, перетворивши його на суб'єкт. Студент стає співавтором лекції, семінарського заняття тощо. Підхід до студента, який знаходиться у центрі процесу навчання, грунтується на повазі до його думки, на спонуканні до активності, на заохоченні до творчості [7].

Процес підготовки лікарів у медичних університетах Австрії передбачає застосування широкого спектра методів навчання майбутніх лікарів. Застосування методів навчання, їх вибір обгрунтовані поставленими цілями, які викладач ставить перед собою.

Серед методів теоретичної підготовки, що застосовуються на лекціях, практичних заняттях і для організації самопідготовки студентів австрійських вищих медичних закладів, найбільш поширеними є: пояснення, бесіда, інструктаж, навчальна дискусія, диспут, проблемний виклад матеріалу.

Методи практичної підготовки дозволяють студентам закріплювати, застосовувати і розширювати знання, отримані в ході теоретичної підготовки, а також формувати практичні уміння та навички. У медичних університетах Австрії застосовують різні методи практичного навчання, такі, як лабораторні роботи, аналіз ситуацій, клінічні сценарії, навчання на основі клінічних випадків, тренувальні вправи, планування і моделювання професійної діяльності, участь у наукових дослідженнях, вивчення й аналіз історій хвороб та протоколів розтину [12].
Потік інформації у сучасному світі вимагає застосування таких методів навчання, які дозволили б ефективно передавати доволі великий обсяг знань, забезпечили високий рівень оволодіння матеріалом, який вивчається. Суть їх полягає у тому, що навчальний процес організовується на основі взаємодіï, діалогу, в ході якого студенти вчаться критично мислити, вирішувати складні проблеми за допомогою аналізу обставин і відповідної інформації, враховувати альтернативні думки, приймати продумані рішення, брати участь у дискусіях, спілкуватися з іншими людьми [10].

Проблема впровадження інтерактивних методів навчання у практику вищої медичної освіти Австрії $€$ вельми актуальною, оскільки розвиток освіти, ії орієнтація спрямовані не стільки на отримання конкретних знань, скільки на формування професійної компетентності, а також на вимоги до якості медичного фахівця, який повинен володіти здатністю оптимальної поведінки в різних ситуаціях.

Виходячи з того, що навчання є процесом соціальним, колективним, а не суто індивідуальним, одним із таких методів є робота в малих групах.

Робота в малих групах - це одна з найпопулярніших стратегій, оскільки вона дає всім студентам можливість брати участь у роботі, практикувати навички співробітництва, міжособистісного спілкування (зокрема, вміння активно слухати, виробляти спільну думку, вирішувати виникаючі розбіжності). Все це часто буває неможливо у великому колективі [5].

Робота в групах - це спільна діяльність для досягнення загальних цілей. Робота в групах передбачає розподіл групи на колективи з 3-5 студентів. Під час виконання завдань виділяється лідер, який бере на себе інтелектуальне керівництво групою. Групові форми роботи сприяють формуванню в студентів демократичного самоусвідомлення та почуття власної гідності. Студент відчуває себе особистістю, яка має право на вибір і ініціативу, а разом з тим готова толерантно ставитися до свого оточення, погоджувати свої дії з діями та інтересами інших членів групи.

Така організація спрямована на те, щоб не давати готових відповідей, а націлювати студентів на творчий пошук, на формування власної думки.

Навчання в групах - це створення різних груп, де студенти допомагають один одному й навчають один одного. Це вміння ефективно працювати в команді пригодиться їм у подальшому житті [7].

Використання методу аналізу ситуащуій ("кейс"методу) в навчанні студентів-медиків дозволяє підвищити пізнавальний інтерес до навчальних дисциплін, 
сприяє розвитку дослідницьких, комунікативних i творчих здібностей. 3 урахуванням певних правил розробляється модель конкретної ситуації, яка має місце у реальному житті, і відбиває той комплекс знань і практичних навичок, які студентам потрібно отримати; при цьому викладач виступає в ролі ведучого, який генерує питання, фіксує відповіді, підтримує дискусію, тобто в ролі посередника у процесі співпраці.

Позитивною стороною методу ситуаційного аналізу є не тільки отримання знань і формування практичних навичок, але і розвиток системи цінностей студентів, професійних позицій, життєвих установок, своєрідного професійного світовідчуття [8].

Суть методу полягає у використанні конкретних випадків, ситуацій, історій, тексти яких називаються “кейсом" (з англ. case - випадок) для спільного аналізу, обговорення та вирішення проблеми, яка має багато альтернативних шляхів та методів вирішення [14]. Цінність кейс-методу полягає в тому, що він одночасно відображає не тільки практичну проблему, а й актуалізує певний комплекс знань, який необхідно засвоїти при вирішенні цієї проблеми, а також вдало суміщає навчальну, аналітичну і виховну діяльність, що безумовно є діяльним і ефективним у реалізації сучасних завдань системи освіти. Робота над кейсом передбачає: розбір конкретної ситуації 3 певного сценарію, який включає самостійну роботу; “мозковий штурм” у межах малої групи; публічний виступ із представленням та захистом запропонованого рішення; контрольне опитування учасників на предмет знання фактів кейсу, що розбирається. Студенти формують міні-групи по 3-5 чоловік. Командам надається по одному структурованому кейсу (highly structured case), що відображає конкретну реальну клінічну ситуацію, та містить окрім текстового опису ще й сканограми лабораторних аналізів, аудіозаписи, ілюстрації рентгенологічного дослідження (рентгенограми, томограми) та ін. Проблемна ситуація може бути висвітлена як при вивченні нової теми у викладенні теоретичного матеріалу, так і може використовуватися з метою узагальнення та систематизації матеріалу. Викладач контролює роботу малих груп, допомагає, уникаючи прямих консультацій. Студенти можуть використовувати допоміжну літературу, підручники, довідники. У ході заняття можливі питання до виступаючого, виступи і доповнення членів групи, викладач слідкує за ходом полілогу і шляхом поетапної дискусії обирається спільне вирішення проблемної ситуації. Викладач має бути досить емоційним протягом всього процесу навчання, вирішувати і не допускати конфлікти, створювати обстановку співпраці і конкуренції одночасно, забезпечувати дотримання особистих прав студента.

Метод аналізу ситуацій дозволяє застосувати теоретичні знання для вирішення практичних завдань. Метод сприяє розвитку у майбутніх лікарів самостійного мислення, уміння вислуховувати і враховувати альтернативну точку зору, аргументовано висловити свою. За допомогою цього методу студенти мають можливість проявити і удосконалити аналітичні навички, навчитися працювати в команді, знаходити найбільш раціональне вирішення поставленої проблеми [13].

Навчання на основі клінічних випадків - розробка “банку” нетипових клінічних випадків, які ілюструють різні аспекти перебігу різноманітних захворювань і патологічних станів. Вони можуть включати:

- історії хвороби / виписки з історії хвороби;

-проведені дослідження і результати: лабораторні аналізи, рентгенологічне, ультразвукове дослідження тощо;

- відео-та аудіозаписи обстежень пацієнта;

- витяги з відповідних статей про клінічний стан, лікування тощо.

Навчання на основі клінічних випадків використовується для того, щоб студенти мали можливість отримати більше інформації про специфічні клінічні ситуації. Це може бути корисним у випадку, коли спостерігається нетиповий перебіг типових захворювань, зумовлений віковими, статевими, генетичними та іншими факторами [9].

Клінічні сценарії - написання типових клінічних сценаріїв, що використовуються як матеріал для обговорення і заохочують студентів до пошуку додаткової інформації з певної теми. Сценарії можуть охоплювати не тільки клінічні питання, але і юридичні або етичні, питання охорони здоров'я, розподілу ресурсів і т. д. Клінічні сценарії можуть включати:

- газетні вирізки про клінічні випадки;

- статті з медичних журналів;

- звіти та рекомендації від державних органів або установ;

- статистичні звітності із зазначенням тенденцій захворюваності на певні нозологічні форми.

У сценаріях описується стан пацієнта, симптоми, цілі, необхідне обладнання і медикаменти, рівень ризику [13].

Планування $і$ моделювання професійної діяльності є корисними для стимулювання дискусії та обговорення певних клінічних питань. Використання “умовних пацієнтів" є особливо ефективним для навчання збору анамнезу, особливо у сфері взаємовідносин лікаря і пацієнта. Метод моделювання дозволяє проводити опитування “умовного пацієнта” у зручний час і в зручному місці, опитування може бути 
зупиненим і будь-які незрозумілі питання чи проблеми можна вільно обговорювати у присутності “пацієнта", крім того, немає ризику образити або зашкодити “пацієнту”. Даний метод використовується також для моделювання ситуацій, у яких необхідно використовувати певні технології, наприклад, для аускультації серця, обстеження молочних залоз, пальпації передміхурової залози, обстеження гортані тощо [11].

Висновок. Інтерактивні методи навчання дозволяють інтенсифікувати освітній процес, збільшити швидкість сприйняття, розуміння та глибину засвоєння величезних масивів знань, забезпечують високу мотивацію, міцність знань, творчість і фантазію; розвивають комунікабельність, активну життєву позицію, командний дух, цінність індивідуальності та свободу самовираження.

За умови вмілого впровадження інтерактивні методи навчання дозволяють залучити до роботи всіх

\section{Література}

1. Войцещук Л. Є. Інтерактивне навчання - технологія сучасного навчання / Л. С. Войцещук // Вісник Запорізького національного університету. -2011. - № 3(15). - С. 46-49.

2. Ісакова Н. М. Інтерактивний метод навчання студентів дитячій хірургічній стоматології / Н. М. Ісакова, Ю. В. Філімонов, А. Л. Зєлінський // Вісник Вінницького національного медичного університету. - 2011. - № 15(2). -C. 401-404.

3. Корж А. А. О воспитании клинического и аналитического интегративного мышления врача / А. А. Корж// Международный мед. журнал. -2006. - Т. 12, № 1.-С. 122-124.

4. Мілерян В. С. Методичні основи підготовки та проведення навчальних занять в медичних вузах : метод. посібник / В. С. Мілерян. - К. : Хрещатик, 2006. -80 с.

5. Нагайчук В. В. Застосування інтерактивних технологій навчання у вищих медичних навчальних закладах / В. В. Нагайчук // Вісник Вінницького національного медичного університету. - 2013. - № 2(17). - С. 456-459.

6. Стратегія розвитку медичної освіти в Україні визначена. [Електронний ресурс]. - Режим доступу: $<$ http:// www.osvita.org.ua/bologna/vprov/articles/01.html $>-$ Загол. з екрана. - Мова укр.

7. Ткачук Ю. П. Практичні засади використання інтерактивних методів при викладанні інформатики у Чернівецькому медичному коледжі БДМУ / Ю. П. Ткачук // Інноваційна діяльність та дослідно-експериментальна робота в сучасній освіті - 2013 : матеріали I Всеукраїнської наук.практ. інтернет-конф., 18 квітня 2013 р. [Електронний ресурс]. - Режим доступу до інф. : http://ippobuk.cv.ua/ студентів групи, сприяють виробленню соціально важливих навичок роботи в колективі, взаємодії 3 колективом, навичок проведення чи підтримки дискусії, обговорення запропонованих тем, дозволяють підвищити ефективність засвоєння фактичного матеріалу; удосконалити практичні навички клінічного застосування теоретичних знань; сприяє професіоналізації студента; розвитку особистісних та професійних якостей майбутнього медичного фахівця.

Завдяки інтерактивним методам навчання студенти набувають культури дискусії; вчаться приймати спільні рішення; покращують уміння спілкуватись, доповідати; якісно змінюють рівень сприйняття.

Таким чином, інтерактивні форми навчання сприятливо впливають на розвиток особистості та інтелекту, приносять більш високі навчальні результати порівняно з традиційними формами і методами.

index.php/2012-12-06-16-13-32/2012-12-06-16-15-44/2012-1221-14-45-27/2012-12-11-20-55-13/1096?task=-view.

8. Jamoulle M. Eine anspruchsvolle und innovative Form der Ausbildung in Medizin / M. Jamoulle // Primary Care. 2010. - Vol. 10, № 19. - S. 375-378.

9. Jaques D. ABC of learning and teaching in medicine. Teaching small groups / D. Jaques // BMJ. - 2003. - Vol. 326. P. 326-329.

10. Korst R. A handbook for teachers in universities and colleges: a guide to improving teaching methods / R. Korst, D. Newble, R. Cannon // Medical Teacher. - 1994. - № 32. P. 46-49.

11. Learning performance with interactive simulations in medical education: Lessons learned from results of learning complex physiological models with the haemodynamics simulator [Електронний ресурс] / A. Holzinger, S. Wassertheurer, M. Hessinger // Computer Education. -2009. - Vol. 52, № 2. - P. 292-301.

12. Mitteilungsblatt der Medizinischen Universitat Wien [Електронний ресурс]. - Режим доступу до інф. : http:// www.meduniwien.ac.at/studienabteilung/content/studiumlehre/studienangebot/n202/studienplan.

13. Schwarzkopf S. R. Aktuelle Lehr-, Lern- und Prufungsmethoden in der medizinischenAusbildung und ihre Anwendungsmoglichkeiten fur die Rehabilitation / S. R. Schwarzkopf, M. Morfeld, M. Gulich // Rehabilitation.2007. - Vol. 46, № 2. - S. 64-67.

14. Susan S. The case study as a research method / S. Susan. - University of Texas atAustin, 1997. - 54 p.

Отримано 05.08.14 